\title{
Molecular phylogeny and biogeographic history of the Neotropical tribe Glandulocaudini (Characiformes: Characidae: Stevardiinae)
}

\author{
Priscila Camelier ${ }^{1}$, Naércio Aquino Menezes ${ }^{1}$, Guilherme José Costa-Silva ${ }^{2,3}$ and \\ Claudio Oliveira ${ }^{3}$
}

\begin{abstract}
Although former studies on systematics and biogeography represent a progress on the knowledge of the tribe Glandulocaudini, none was grounded on molecular evidence. Thus, the first hypothesis of relationships for the tribe based on a multilocus analysis is presented, including all genera and most of the valid species. DNA sequences of Glandulocauda caerulea and Mimagoniates sylvicola were analyzed for the first time. A molecular clock analysis was used to estimate the origin of the Glandulocaudini and the approximate timing of cladogenetic events within the group. Glandulocaudini was recovered as monophyletic. No hypothesis recovered Glandulocauda as monophyletic, since G. melanopleura is sister to Lophiobrycon weitzmani while G. caerulea is closely related to Mimagoniates. The relationships within the latter genus were resolved. The molecular clock results indicate the origin of the Glandulocaudini during the Miocene with diversification in the group occurring from Neogene to Pleistocene. These results corroborated the hypothesis that its origin took place on the Brazilian crystalline shield with the subsequent occupation of the Atlantic Coastal drainages. Apparently, Pleistocene sea-level fluctuations might have shaped the distribution pattern of some species in Glandulocaudini.
\end{abstract}

Keywords: Brazilian Crystalline Shield, Coastal Drainages, Molecular Clock, Molecular Systematics, Multilocus Analysis.

Embora estudos prévios sobre sistemática e biogeografia representam um avanço no conhecimento da tribo Glandulocaudini, nenhum foi baseado em evidência molecular. Assim, a primeira hipótese de relações para a tribo com base em uma análise multilocus é apresentada, incluindo todos os gêneros e a maioria das espécies válidas. Sequências de DNA de Glandulocauda caerulea e Mimagoniates sylvicola foram analisadas pela primeira vez. Uma análise de relógio molecular foi utilizada para estimar a origem de Glandulocaudini e datas aproximadas de eventos cladogenéticos dentro do grupo. Glandulocaudini foi recuperada como monofilética. Nenhuma hipótese recuperou Glandulocauda como monofilético, uma vez que $G$. melanopleura é irmã de Lophiobrycon weitzmani e G. caerulea está proximamente relacionada a Mimagoniates. As relações dentro deste último gênero foram resolvidas. Os resultados do relógio molecular indicam que Glandulocaudini originouse durante o Mioceno, com diversificação dentro do grupo ocorrendo desde o Neogeno até o Pleistoceno. Estes resultados corroboram a hipótese da sua origem no escudo cristalino brasileiro, com a subsequente ocupação das drenagens costeiras atlânticas. Aparentemente, as flutuações pleistocênicas do nível do mar podem ter moldado o padrão de distribuição de algumas espécies em Glandulocaudini.

Palavras-chave: Análise Multilocus, Drenagens Costeiras, Escudo Cristalino Brasileiro, Relógio Molecular, Sistemática Molecular.

\section{Introduction}

The name Glandulocaudinae was originally proposed by Eigenmann (1914: 34) as a subfamily within Characidae to include 11 genera defined by remarkable sexual dimorphism. The history of the classification and hierarchical composition of the group is complex and Glandulocaudinae was already considered as a family (Glandulocaudidae, e.g., FernándezYépez, Anton, 1966) and as a tribe (Glandulocaudini, e.g., Myers, Böhlke, 1956; Menezes, Weitzman, 1990; Mirande, 2010). Menezes, Weitzman (2009), based on morphological data, reviewed the systematics of the glandulocaudines and discussed in detail the taxonomic history and the nomenclatural issues involving the group, and these are not repeated here.

\footnotetext{
${ }^{1}$ Laboratório de Ictiologia, Museu de Zoologia, Universidade de São Paulo, Av. Nazaré, 481, Ipiranga, 04263-000 São Paulo, SP, Brazil. (PC) pricamelier@gmail.com, Dhttps://orcid.org/0000-0002-1228-0076 (corresponding author), (NAM) naercio@usp.br

${ }^{2}$ Universidade Santo Amaro, Campus I, Rua Prof. Enéas de Siqueira Neto, Jardim das Imbuias, 04829-300 São Paulo, SP, Brazil. costasilvagj@gmail.com

${ }^{3}$ Laboratório de Biologia e Genética de Peixes, Departamento de Morfologia, Instituto de Biociências, Universidade Estadual Paulista Júlio Mesquita Filho, Distrito Rubião Jr., 18618-970 Botucatu, SP, Brazil. claudio@ibb.unesp.br
} 
Also, in that paper, the authors recognized Glandulocaudinae as monophyletic and closely related to Stevardiinae. More recently, Thomaz et al. (2015a) analyzed the phylogenetic relationships within Stevardiinae based on molecular data and proposed Glandulocaudinae sensu Menezes, Weitzman (2009) as tribe Glandulocaudini within that subfamily. Although they represent different hierarchical categories, Glandulocaudinae sensu Menezes, Weitzman (2009) and Glandulocaudini sensu Thomaz et al. (2015a) correspond to the same group of Neotropical freshwater fishes, including the genera Glandulocauda Eigenmann, Lophiobrycon Castro, Ribeiro, Benine, Melo, and Mimagoniates Regan, and ten species distributed in freshwater environments of eastern and southern Brazil, Paraguay, and northeastern Uruguay (Menezes, Weitzman, 2009; Eschmeyer et al., 2017). Species of Glandulocaudini are recognized by the possession of different forms of a caudal-fin organ of males that apparently secretes one or more pheromones during courtship (Weitzman, Fink, 1985; Weitzman et al., 1988; Menezes, Weitzman, 2009). Representatives of this tribe are relatively small (25$60 \mathrm{~mm}$ in standard length as adults), attractively colored, apparently adapted to restricted habitats, and have a limited distribution due their ecological habits (Weitzman et al., 1988; Menezes, Weitzman, 1990, 2009).

The genus Lophiobrycon, which comprises a single valid species, L. weitzmani Castro, Ribeiro, Benine, Melo, was described from headwaters of the rio Grande basin, an affluent of the upper rio Paraná basin (Castro et al., 2003), and is restricted to the southeastern portion of the Brazilian crystalline shield (Menezes et al., 2008). Currently, there are two valid species of Glandulocauda: G. caerulea Menezes, Weitzman and G. melanopleura (Ellis). Glandulocauda caerulea was described from the upper rio Iguaçu, main tributary to the rio Paraná basin, and is also considered endemic to southeastern parts of the Brazilian crystalline shield, occurring in upland areas of the rio Iguaçu basin in Paraná and Santa Catarina States (Menezes et al., 2008; Menezes, Weitzman, 2009). Glandulocauda melanopleura was described based on specimens from a headwater stream of the rio Tietê drainage (upper rio Paraná basin) and is also known from adjoining upper portions of the coastal rivers Guaratuba, Itatinga, Itanhaém, and Ribeira de Iguape flowing into the Atlantic Ocean in São Paulo State, Brazil (Ribeiro et al., 2006; Serra et al., 2007; Menezes et al., 2008; Menezes, Weitzman, 2009; Camelier, 2016). Mimagoniates is the most species-rich genus including seven valid species: $M$. barberi Regan, $M$. inequalis (Eigenmann), M. lateralis (Nichols), $M$. microlepis (Steindachner), M. pulcher Menezes, Weitzman, $M$. rheocharis Menezes, Weitzman, and M. sylvicola Menezes, Weitzman. Except for M. barberi, M. pulcher, and a few populations of $M$. microlepis that occur in upper portions of some tributaries to the upper rio Paraná basin, the species of Mimagoniates are mostly found in restricted stretches of lowland Brazilian coastal rivers from Bahia to Rio Grande do Sul States. Mimagoniates barberi, type species of the genus, is known from small tributaries to the Paraguay and Paraná rivers, in Paraguay, and M. pulcher is only known from the type locality, in the upper rio Paraguay, Mato Grosso State, Brazil (Menezes, Weitzman, 2009). Overall, as Lophiobrycon and Glandulocauda, most species of Mimagoniates have restricted distributions with high recognized endemism. Mimagoniates microlepis is the only exception since, as mentioned above, occurs in coastal basins from southern Bahia to northern Rio Grande do Sul States and additionally in the upper Iguaçu, Tibagi, and Tietê rivers, southeastern border of the upper rio Paraná basin (Menezes et al., 2008; Menezes, Weitzman, 2009; Camelier, 2016).

The systematics of Glandulocaudini is historically confuse and only after restriction of the group to Lophiobrycon, Glandulocauda, and Mimagoniates by Weitzman et al. (2005), it was possible to discuss more clearly the phylogenetic relationships among its species (Menezes, Weitzman, 2009). In that paper, Menezes, Weitzman provided the most recent phylogenetic hypothesis for Glandulocaudini as currently recognized, including all known species and based mostly on analyses of primary and especially secondary sexual characters of males. According to their hypothesis, Glandulocaudini was recovered as a monophyletic group, but some relationships within the tribe were uncertain ( $c f$. Menezes, Weitzman, 2009: fig. 2). Representatives of Glandulocaudini were included in phylogenetic studies based on molecular data by Calcagnotto et al. (2005), Javonillo et al. (2010), Oliveira et al. (2011), and Thomaz et al. (2015a). However, neither of them focused their work on the tribe as a whole and just a few species were analyzed leaving evolutionary issues involving the tribe unsolved. Furthermore, Glandulocaudini has an interesting distributional pattern, characterized by endemic species restricted to lowland areas along Brazilian coastal drainages and others endemic to upland areas of the Brazilian crystalline shield, in addition to species that are shared between both areas. This pattern was already used as example to explain or to propose biogeographic hypotheses (e.g., Buckup, 2011; Lima, Ribeiro, 2011; Camelier, Zanata, 2014; Ribeiro et al., 2016). Menezes et al. (2008) reviewed the biogeography of the Glandulocaudini (former Glandulocaudinae), discussed some hypotheses, and suggested that additional molecular data should be used to test and better understand the evolutionary history of the group.

This study has four aims: (1) to propose a robust hypothesis of phylogenetic relationships for the tribe based on the analysis of all genera and $80 \%$ of the valid species in a multilocus dataset; (2) to estimate divergence times within the tribe based on molecular clock analysis; (3) to test previously proposed biogeographic hypotheses; and (4) to update the information on Glandulocaudini distribution based on additional material.

\section{Material and Methods}

Taxon sampling, DNA extraction, and sequencing. Three genera and eight of ten species of Glandulocaudini were included as ingroup. Tissue samples for $M$. barberi and $M$. 
pulcher were not available for this study. Whenever possible, sequences of at least two individuals of each species were analyzed. Since M. microlepis is the only widespread species, it was sampled across its distributional range and this species had more sequences included in the analyses. The representatives of all remain tribes of Stevardiinae proposed by Thomaz et al. (2015a) were included as outgroup: Creagrutini, Diapomini, Eretmobryconini, Hemibryconini, Stevardiini, and Xenurobryconini; plus Argopleura chocoensis (Eigenmann), which was considered by authors as incertae sedis within the subfamily. In addition to that, sequences of four nonstevardiin species were included: Charax stenopterus (Cope), Cheirodon ibicuhiensis Eigenmann, Spintherobolus leptoura Weitzman, Malabarba, and Bryconops caudomaculatus (Günther). Tissue samples from glandulocaudin species, with the exception of $L$. weitzmani, were obtained from fish collections or field expeditions conducted between 2012 and 2015. All the species collected are deposited in the Laboratório de Biologia e Genética de Peixes (LBP), Departamento de Morfologia, Instituto de Biociências, Universidade Estadual Paulista, Botucatu, São Paulo, and the Museu de Zoologia da Universidade de São Paulo (MZUSP), São Paulo, Brazil. Sequences of all non-glandulocaudin species (except $S$. leptoura) and L. weitzmani were obtained from the GenBank database deposited by Thomaz et al. (2015a); sequences of S. leptoura were deposited by Oliveira et al. (2011). All glandulocaudin specimens' vouchers, including $L$. weitzmani, were identified to species level based on diagnostic morphological traits. Species used as outgroups in the phylogenetic analyses, identification codes of samples, specimens' vouchers, and GenBank accession numbers are given in (S1 - Available only as online supplementary file accessed with the online version of the article at http:// www.scielo.br/ni). Institutional abbreviations follow Fricke, Eschmeyer (2017), with the inclusion of the tissue collection of the Museu de Zoologia da Universidade de São Paulo (MZict).

Total genomic DNA was extracted from muscle and fin tissues preserved in $96 \%$ ethanol with a DNeasy Blood and Tissue Kit (Qiagen), according to manufacturer's instructions. Partial sequences of two mitochondrial genes (16S rRNA and cytochrome $\mathrm{c}$ oxidase subunit I, COI) and one nuclear (recombination activating gene 2, RAG2) were amplified by polymerase chain reaction (PCR) with the primers described by Palumbi (1996: 16S rRNA), Ward et al. (2005: COI) and Oliveira et al. (2011: RAG2). Amplifications of the mitochondrial genes were performed in a total volume of $12.5 \mu \mathrm{l}$, with $1.25 \mu \mathrm{l}$ of $10 \mathrm{X}$ buffer $(10 \mathrm{mM}$ Tris- $\mathrm{HCl}+15$ $\mathrm{mM} \mathrm{MgCl}$ ), $0.375 \mu \mathrm{l} \mathrm{MgCl}_{2}(50 \mathrm{nM}), 0.5 \mu \mathrm{l}$ dNTPs $(200$ $\mathrm{nM}$ of each), $0.25 \mu$ leach $5 \mathrm{mM}$ primer, $0.05 \mu$ l Platinum Taq Polymerase (Invitrogen), $9.075 \mu$ lof double-distilled water, and $1 \mu \mathrm{l}$ template DNA(12 ng). The thermo-cycler profile consisted of an initial denaturation step at $95^{\circ} \mathrm{C}$ for five min; followed by 35 cycles of chain denaturation $\left(45 \mathrm{~s}\right.$ at $\left.95^{\circ} \mathrm{C}\right)$, annealing $(30 \mathrm{~s}$ at $52^{\circ} \mathrm{C}$ for $16 \mathrm{~S}$ and $54^{\circ} \mathrm{C}$ for $\mathrm{COI}$ ), and nucleotide extension (one min at $72^{\circ} \mathrm{C}$ ); plus a final extension step at $72^{\circ} \mathrm{C}$ for seven min. Amplifications of RAG2 were performed in a total volume of $12.5 \mu \mathrm{l}$, with $1.25 \mu \mathrm{l}$ of $10 \mathrm{X}$ buffer $(10 \mathrm{mM}$ Tris$\left.\mathrm{HCl}+15 \mathrm{mM} \mathrm{MgCl}_{2}\right), 0.375 \mu \mathrm{l} \mathrm{MgCl}(50 \mathrm{nM}), 0.5 \mu \mathrm{dNTPs}$ (200 nM of each), $0.25 \mu$ l each $5 \mathrm{mM}$ primer, $0.08 \mu \mathrm{l}$ Platinum Taq Polymerase, $8.795 \mu \mathrm{l}$ of double-distilled water, and $1 \mu \mathrm{l}$ template DNA (12 ng). Nested-PCRs were used to amplify this gene following the procedures detailed in Oliveira et al. (2011). The thermo-cycler profile consisted of an initial denaturation step at $95^{\circ} \mathrm{C}$ for three min; followed by 30 cycles divided into two stages: (1) 15 initial cycles of chain denaturation (45 s at $94^{\circ} \mathrm{C}$ ), annealing $\left(45 \mathrm{~s}\right.$ at $56^{\circ} \mathrm{C}$ for first $\mathrm{PCR}$ and $58^{\circ} \mathrm{C}$ for second PCR), and nucleotide extension (two $\min$ at $72^{\circ} \mathrm{C}$ ) and (2) 15 final cycles of chain denaturation $\left(45 \mathrm{~s}\right.$ at $\left.94^{\circ} \mathrm{C}\right)$, annealing (45 s at $54^{\circ} \mathrm{C}$ for first PCR and $56^{\circ} \mathrm{C}$ for second PCR), and nucleotide extension (two $\mathrm{min}$ at $72^{\circ} \mathrm{C}$ ); plus a final extension step at $72^{\circ} \mathrm{C}$ for seven min. The PCR products were first visually identified on a $1 \%$ agarose gel and then purified using ExoSap-IT® (USB Corporation) following the instructions of the manufacturer. The purified PCR products were sequenced using the "Big DyeTM Terminator v 3.1 Cycle Sequencing Ready Reaction Kit" (Applied Biosystems), purified again by ethanol precipitation and loaded on an automatic sequencer 3130-Genetic Analyzer (Applied Biosystems) in the Instituto de Biociências, Universidade Estadual Paulista, Botucatu, São Paulo, Brazil. All sequences were read twice (forward and reverse). All sequences produced in this study were deposited in GenBank.

Alignment, phylogenetic analyses, and estimation of divergence times. Electropherograms were inspected and assembled in contigs from forward and reverse strands using Geneious v. 4.8 .5 (http://www.geneious.com, Kearse et al., 2012). Sequences of each gene were independently aligned using the MUSCLE algorithm under default parameters (http://www.ebi.ac.uk/Tools/msa/muscle/, Edgar, 2004). After alignments, the matrix was checked visually for any obvious misalignments and to detect potential cases of sequencing error due to contamination, paralogy, or pseudogenes using Geneious and BioEdit v. 7.0.9.0 (Hall, 1999). Nucleotide variation and substitution patterns were examined using MEGA v. 5.0 (Tamura et al., 2011). To evaluate the occurrence of substitution saturation in the sequences, the index of substitution saturation (Iss) described by Xia et al. (2003) and Xia, Lemey (2009) in DAMBE 5.3.48 (Xia 2013) was estimated.

The mitochondrial and nuclear genes were concatenated into a single matrix, which was partitioned by gene and used to perform all phylogenetic and molecular clock analyses. Only specimens with sequences for all genes were included in the matrix. Phylogenetic relationships among species of Glandulocaudini and between this tribe and outgroups were inferred by Bayesian inference (BI) and Maximum-likelihood (ML) methods. Sequences of Bryconops caudomaculatus, the most external characiform in the dataset, were used to root the phylogenetic analyses. The best-fit nucleotide evolution model was estimated independently for each partition using 
MrModeltest v. 2.2 (Nylander, 2004) based on the Akaike Information Criterion (AIC), in conjunction with PAUP* (Swofford, 1998). BI analysis was conducted in MrBayes v. 3.2.6 (Ronquist et al., 2012). Two independent Bayesian runs of 20 million generations with four chains of Markov chain Monte Carlo (MCMC) each were performed, saving trees each 500 generations. Chain convergence (Effective Sample Size - ESS values > 200) was checked using the likelihood plots for each run using Tracer v. 1.5.1 (Rambaut, Drummond, 2009). The Potential Scale Reduction Factor (PSRF) was also used to check chain convergence and burnin; values close to one indicate good convergence between runs (Gelman, Rubin, 1992). After a graphical analysis of the evolution of the likelihood scores, and checking for the stationarity of all model parameters, the first four thousand generations $(10 \%)$ were discarded as burn-in. The remaining trees were used to calculate the consensus tree and posterior probability values were calculated to determine the level of support to the Bayesian topology. The ML phylogenetic reconstructions were performed using RAxML v. 8.0.24 (Stamatakis, 2014), random starting trees, and a GTRGAMMA model of nucleotide substitution. One thousand bootstrap pseudoreplicates were used to investigate the support of each node in the most likely topology. In general, bootstrap values above $75 \%$ in the ML analyses were interpreted as well supported, and in the BI analyses, a posterior probability value of 0.99 was taken as a threshold. MrBayes and RAxML analyses were performed remotely at the CIPRES Science Gateway portal (Miller et al., 2010).

Divergence time estimates were obtained by implementing a Bayesian relaxed clock model in BEAST v. 1.7.2 (Drummond et al., 2012) using the concatenated dataset in CIPRES web portal and all clade-age inferences are presented as $95 \%$ highest posterior density (HPD). A relaxed clock with an uncorrelated lognormal distribution was used (Drummond et al., 2006); a starting tree was obtained from the Bayesian analysis; a macroevolutionary Birth-Death model for the diversification likelihood values; and under GTR $+\mathrm{I}+\mathrm{G}$ model (as estimated in MrModeltest). Two calibration points were included based on fossil records of the characids $\uparrow$ Paleotetra Weiss, Malabarba, Malabarba (Eocene-Miocene, Weiss et al., 2012) and $\uparrow$ Megacheirodon unicus (Travassos, Santos) (Late Oligocene-Early Miocene, Malabarba, 1998; Bührnheim et al., 2008). According to Mirande et al. (2013), the genus $\uparrow$ Paleotetra is included in a clade who is closely related to ((Aphyocharacinae (Aphyoditeinae, Cheirodontinae)), Stevardiinae). Thus, the first calibration point was implemented using a lognormal prior offset to 33.9 million years ago (Mya) with a standard deviation of one for the origin of the clade ((C. ibicuhiensis, S. leptoura) Stevardiinae) proposed by the ML starting tree. This estimated date was used based on the numerical age to Eocene-Oligocene (cf. Cohen et al., 2013), horizon proposed to †Paleotetra by Weiss et al. (2012). The second calibration point was implemented using a lognormal prior offset to 27.5 Mya with a standard deviation of one for the origin of the subfamily Stevardiinae. This estimated date was based on the mean of the minimum age of 30-25 Mya proposed to $\uparrow$. unicus (Malabarba, 1998; Bührnheim et al., 2008), which was hypothesized as closely related to Spintherobolus by Bührnheim et al. (2008). Forest (2009) was followed to choose the crown and stem groups. The analysis was performed in two independent runs with 100 million generations each, with parameters sampled every 10,000 steps, and a burn-in of $20 \%$. Convergence between runs and analysis performance were checked using Tracer, and the results were accepted if ESS values were $>200$. The resulting trees were combined in LogCombiner v. 1.7. 2 (Drummond et al., 2012), the consensus species tree with the divergence times was obtained in the TreeAnnotator v. 1.7. 2 (Drummond et al., 2012) and visualized in FigTree v. 1.3.1 (Rambaut, 2009).

\section{Results}

Partial sequences of two mitochondrial (16S and COI) and one nuclear (RAG2) genes were obtained from 205 specimens representing all genera and eight glandulocaudin species (23 specimens, Tab. 1) plus 87 species of the outgroup (182 specimens) (S1 - Available only as online supplementary file accessed with the online version of the article at http://www.scielo.br/ni).

The combined sequence data resulted in a matrix with 1,829 base pairs (bp) with 1,063 conserved and 745 variable. Detailed information for each data matrix is provided in Tab. 2 . The coding sequences did not show insertions, deletions, stop-codons, or sequencing errors due to contamination or paralogy. The Iss index was significantly lower than the Iss.c (critical substitution saturation index), indicating no saturation in either transitions and transversions in both asymmetrical (Iss.cAsym) and symmetrical (Iss.cSym) topologies. The best-fit model of evolution estimated by MrModeltest for the all data matrices (mitochondrial, nuclear, and concatenated dataset) was GTR $+\mathrm{I}+\mathrm{G}$.

A summarized view of the BI and ML trees topologies obtained based on the analyses of the concatenated dataset $(16 \mathrm{~S}+\mathrm{COI}+\mathrm{RAG} 2)$ is shown in Fig. 1a and Fig. 1b, respectively. Both phylogenetic methods produced trees with similar topologies for the outgroup and identical relationships within the Glandulocaudini. An important difference between results of $\mathrm{BI}$ and ML involving the ingroup is related to the position of Glandulocaudini within the Stevardiinae. Under BI analysis, Glandulocaudini is recovered as sister group to Stevardiini (Fig. 1a), while under ML it evolved as closely related to a clade composed by ((Creagrutini, Diapomini) Hemibryconini) (Fig. 1b). However, in both hypotheses these relationships had low statistical support ( 0.54 of posterior probability and $39 \%$ of bootstrap), indicating that the position of Glandulocaudini within the Stevardiinae was not clearly resolved. Both BI and ML methods resulted in identical hypotheses of relationships among glandulocaudin species, although statistical support was not strong for some nodes. 
Tab. 1. Species, vouchers, tissue number, and locality information (basin or City and State) for the tissues samples of representatives of Glandulocaudini used in this study. All samples from Brazil, BA = Bahia, ES = Espírito Santo, MG $=$ Minas Gerais, $\mathrm{PR}=$ Paraná, $\mathrm{RS}=$ Rio Grande do Sul, $\mathrm{SC}=$ Santa Catarina, and $\mathrm{SP}=$ São Paulo States. [GenBank accession number ranges: 16S = MG958088-MG958090/MG953575-MG953592; COI = MG967567-MG967588; RAG2 = MG967589-MG967609; and L. weitzmani: 16S = KF209982- KF209983; COI = KF210232- KF210233; and RAG $2=$ KF211223- KF211224].

\begin{tabular}{|c|c|c|c|}
\hline Species & Voucher & Tissue number & Locality (basin or City, State) \\
\hline Lophiobrycon weitzmani & MNRJ 31626 & - & Rio Grande basin, MG \\
\hline Lophiobrycon weitzmani & MNRJ 31664 & - & Rio Grande basin, $\mathrm{MG}$ \\
\hline Glandulocauda caerulea & MZUSP 117479 & MZict 2612 & Rio Iguaçu basin, PR \\
\hline Glandulocauda melanopleura & LBP 4507 & LBP 24538 & Rio Tietê basin, SP \\
\hline Glandulocauda melanopleura & LBP 4507 & LBP 24542 & Rio Tietê basin, SP \\
\hline Mimagoniates inequalis & LBP 3383 & LBP 21275 & Pelotas, RS \\
\hline Mimagoniates inequalis & LBP 3383 & LBP 21277 & Pelotas, RS \\
\hline Mimagoniates lateralis & LBP 70082 & LBP 70082 & Itanhaém, SP \\
\hline Mimagoniates lateralis & LBP 11450 & LBP 52283 & Itapoá, SC \\
\hline Mimagoniates microlepis & LBP 70049 & LBP 70049 & Rio Pardo basin, BA \\
\hline Mimagoniates microlepis & LBP 70048 & LBP 70048 & Rio Itaúnas basin, ES \\
\hline Mimagoniates microlepis & LBP 10756 & LBP 49795 & Rio Paraíba do Sul basin, RJ \\
\hline Mimagoniates microlepis & MUSP 118711 & MZict 2616 & Rio Macacu basin, RJ \\
\hline Mimagoniates microlepis & LBP 6817 & LBP 33039 & Itanhaém, SP \\
\hline Mimagoniates microlepis & LBP 7545 & LBP 36092 & Rio Ribeira de Iguape basin, SP \\
\hline Mimagoniates microlepis & MZUSP 115093 & LBP 70071 & Rio Tietê basin, SP \\
\hline Mimagoniates microlepis & LBP 7170 & LBP 34359 & Morretes, PR \\
\hline Mimagoniates microlepis & LBP 7150 & LBP 34288 & Matinhos, PR \\
\hline Mimagoniates microlepis & LBP 13208 & LBP 55228 & Rio Iguaçu basin, PR \\
\hline Mimagoniates microlepis & LBP 3639 & LBP 21685 & Jaraguá do Sul, SC \\
\hline Mimagoniates rheocharis & UFRGS 12896 & TEC 911C & Rio Araranguá basin, $\mathrm{PR}$ \\
\hline Mimagoniates sylvicola & LBP 70017 & LBP 70017 & Prado, BA \\
\hline Mimagoniates sylvicola & MZUSP 112691 & LBP 70019 & Rio Patipe basin, BA \\
\hline
\end{tabular}

Tab. 2. Information content and characteristics of each dataset used in this study. Number of sequences $=205, \mathrm{bp}$ $=$ base pairs.

\begin{tabular}{|c|c|c|c|c|}
\hline \multirow{3}{*}{ Information } & \multicolumn{4}{|c|}{ Dataset } \\
\hline & \multicolumn{2}{|c|}{ Mitochondrial } & \multirow{2}{*}{$\begin{array}{c}\text { Nuclear } \\
\text { RAG2 }\end{array}$} & \multirow{2}{*}{$\begin{array}{c}\text { Concatenated } \\
16 \mathrm{~S}+\mathrm{COI}+\mathrm{RAG} 2\end{array}$} \\
\hline & $16 \mathrm{~S}$ & $\mathrm{COI}$ & & \\
\hline Length after alignment (bp) & 537 & 522 & 770 & 1829 \\
\hline Number of conserved sites (C) & 333 & 301 & 429 & 1063 \\
\hline Number of variable sites $(\mathrm{V})$ & 184 & 221 & 340 & 745 \\
\hline Singletons (S) & 35 & 23 & 78 & 136 \\
\hline \multicolumn{5}{|c|}{ Nucleotide frequency } \\
\hline $\mathrm{T}$ & 21.2 & 31.8 & 22.6 & 24.9 \\
\hline $\mathrm{C}$ & 22.8 & 25.9 & 25.7 & 24.9 \\
\hline A & 33.0 & 24.9 & 24.8 & 27.3 \\
\hline $\mathrm{G}$ & 23.0 & 17.3 & 26.9 & 22.9 \\
\hline
\end{tabular}

Therefore, only a Bayesian tree with both ML bootstrap values and BI posterior probabilities is presented (Fig. 2). In all phylogenetic analyses, Glandulocaudini is recovered as a strongly supported monophyletic group. None of the results supported the monophyletic status of the genus Glandulocauda as currently recognized, since $G$. melanopleura and G. caerulea were not closely related to each other. According to the phylogenetic hypothesis, G. melanopleura and L. weitzmani are closely related and this clade is sister to (G. caerulea, Mimagoniates). The former clade presented high statistical support in the ML analysis $(90 \%)$, but relatively low in the BI $(0.84)$, while the close relationship between G. caerulea and Mimagoniates was strongly supported in both analyses $(\mathrm{BI}=0.99$ and $\mathrm{ML}=83 \%$ ). The analyzed species of Mimagoniates are resolved as a strongly supported monophyletic group in all phylogenetic hypotheses $(\mathrm{BI}=1$ and $\mathrm{ML}=100 \%$ ). Mimagoniates inequalis and $M$. rheocharis are more closely related to each other, forming a clade sister to $M$. lateralis, and M. microlepis is most closely related to M. sylvicola. All relationships proposed among Mimagoniates species had strong statistical support in both analyses (BI $\geq 0.95$ and $\mathrm{ML} \geq 85 \%$ ). Specimens of $M$. microlepis from different localities, including coastal drainages (from Santa Catarina to Bahia States) plus the upper rio Tietê basin, are herein highly supported as forming a monophyletic group (BI = 0.95 and $\mathrm{ML}=81 \%$ ), with some genetic structuration. 

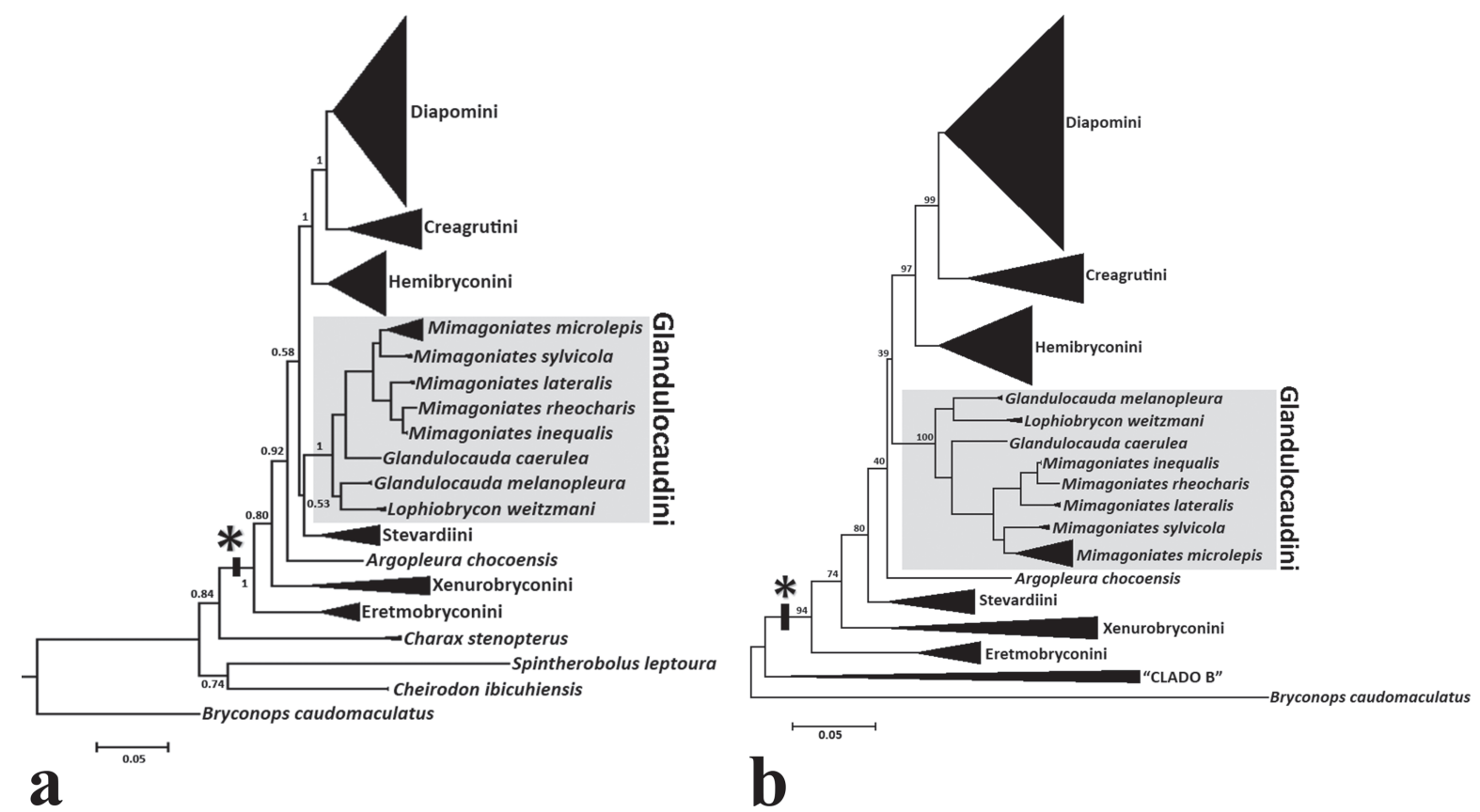

Fig. 1. Abbreviated phylogenetic trees of Stevardiinae (asterisk) obtained in this study based on concatenated dataset $(16 \mathrm{~S}+\mathrm{COI}+\mathrm{RAG} 2,1,829 \mathrm{bp})$, indicating the placement of the tribe Glandulocaudini (highlighted): $\mathbf{a}$. Bayesian tree, numbers at branches are posterior probabilities and b. Maximum likelihood tree, numbers at branches are bootstrap values, "Clade B" $=($ Charax stenopterus (Cheirodon ibicuhiensis, Spintherobolus leptoura $)$ ).

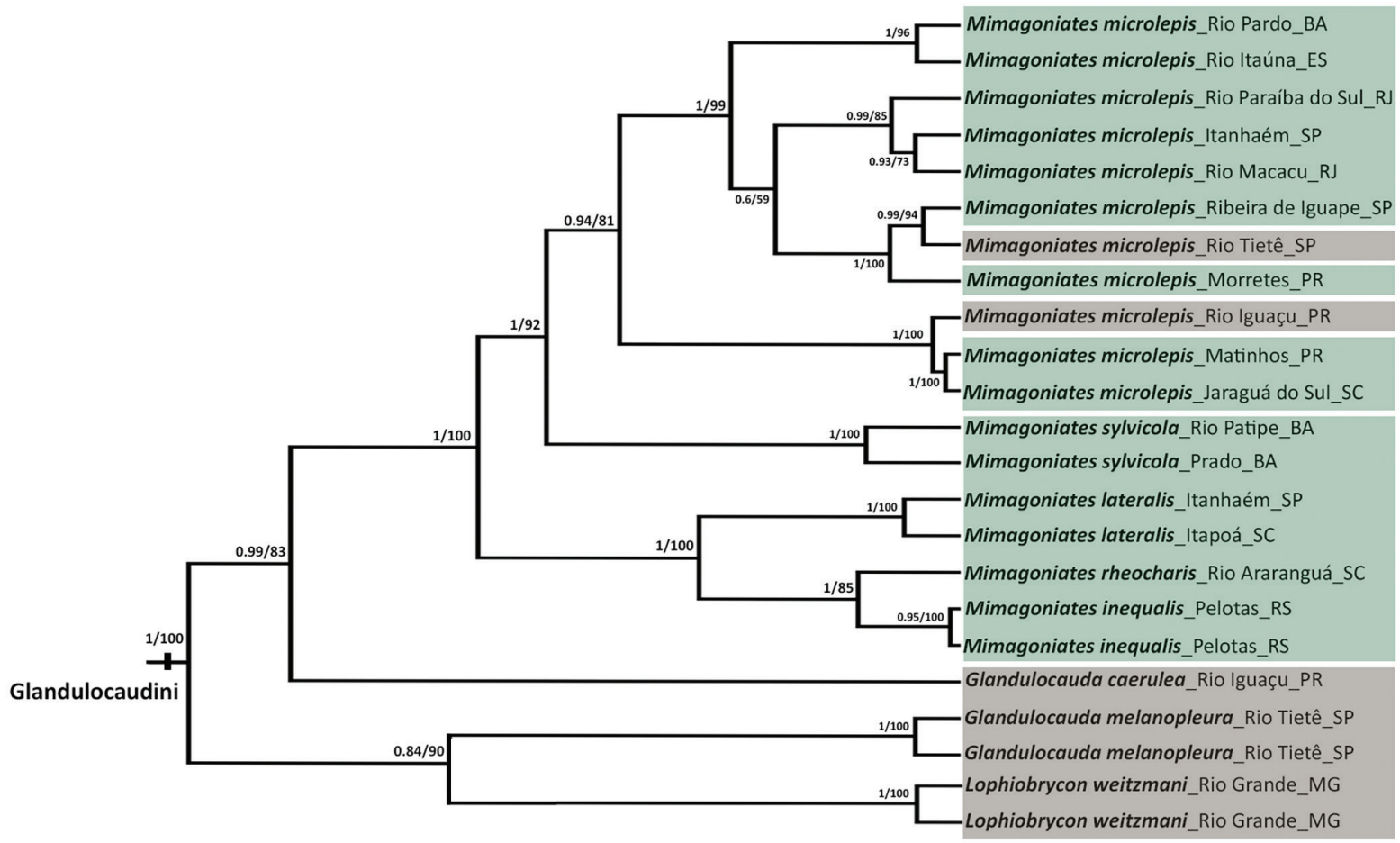

\begin{tabular}{|c|c|c|c|c|c|c|c|}
\hline 14.0 & 10.0 & 8.0 & 6.0 & 4.0 & 2.0 & 0.0 & Million \\
\hline \multicolumn{4}{|c|}{ Miocene } & Pliocene & & & \\
\hline
\end{tabular}

Fig. 2. Calibrated Bayesian tree based on concatenated dataset (16S+COI+RAG2, 1,829 bp) showing the relationships within the Glandulocaudini. Numbers at branches are posterior probabilities and bootstrap values. Species/populations from Brazilian crystalline shield are highlighted in brown (upland areas) and species/populations from Brazilian coastal drainages in green (lowland areas). 
According to the divergence times results (Fig. 2), Glandulocaudini was estimated to have originated during the Miocene (Neogene) about 14.1 Mya (95\% HPD 8.3-21.6 Mya). The oldest split within the tribe was also estimated during the Miocene (10.8 Mya; 95\% HPD 6.0-16.4 Mya) diverging in two main lineages, one of them related to $L$. weitzmani $+G$. melanopleura and the other to the clade G. caerulea plus Mimagoniates. The next cladogenetic event was estimated at 9.4 Mya (95\% HPD 5.2-14.4 Mya), resulting in the split of the ancestral lineage of Mimagoniates from G. caerulea. The split between G. melanopleura and L. weitzmani was more recent, estimated at 7.2 Mya $(95 \%$ HPD 3.2-12.4 Mya). Within Mimagoniates, the cladogenetic events were estimated to have originated near the end of the Miocene about 6.8 Mya (95\% HPD 3.8-10.6 Mya) with the split between the clades ((M. inequalis, $M$. rheocharis $) M$. lateralis) and (M. sylvicola, M. microlepis), and continued until the Pleistocene (Quaternary). The second oldest divergence was the split between $M$. microlepis and $M$. sylvicola, which probably occurred during the Miocene (about 5.8 Mya). Mimagoniates lateralis diverged from ( $M$. inequalis, M. rheocharis) around 3.7 Mya (Pliocene) and the last main cladogenetic event within the genus, which resulted in the split between M. inequalis and M. rheocharis, was very recent, estimated at 1.4 Mya (Pleistocene). Split events among allopatric populations of M. microlepis apparently started in the Pliocene (about 4.8 Mya), but most of them probably occurred during the Pleistocene. The split between the analyzed populations of both $M$. lateralis and M. sylvicola were also estimated for the Pleistocene (about 0.8 and 1.3 Mya, respectively). The collection and analysis of additional representatives of Glandulocaudini indicated that the distribution of the tribe is broader than previously known (e.g., Menezes et al., 2008: fig. 3). Therefore, an updated distribution map is presented in Fig. 3 and these new records are detailed and discussed below.

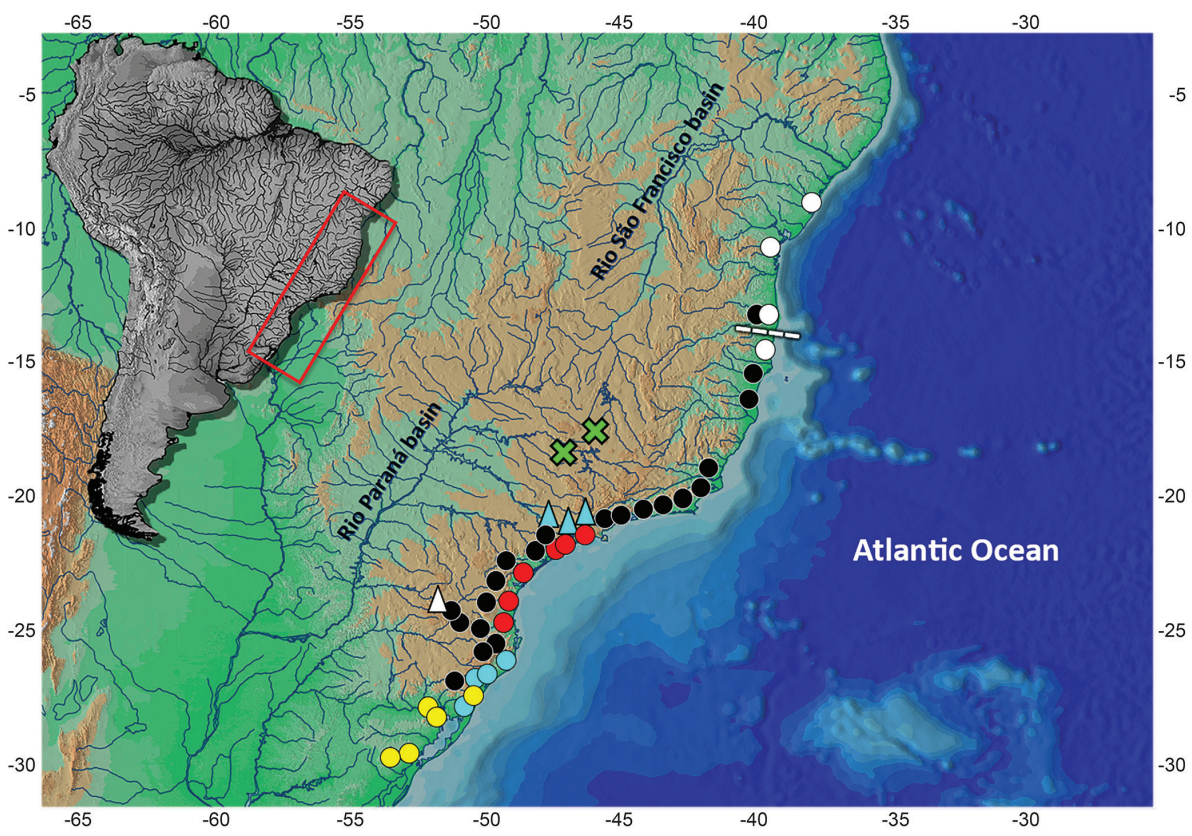

Fig 3. Map showing the updated geographical distribution of Glandulocaudini species analyzed in this study: Glandulocauda caerulea (white triangle), G. melanopleura (blue triangles), Lophiobrycon weitzmani (green crosses), Mimagoniates inequalis (blue circles), M. lateralis (red circles), M. microlepis (black circles), M. rheocharis (yellow circles), and M. sylvicola (white circles). Symbols above the dashed line indicate the northernmost limit of the distribution of Glandulocaudini based on the new records obtained in this study. Some collection points from Menezes et al. (2008: fig. 3).

\section{Discussion}

Monophyly of Glandulocaudini, position within the subfamily Stevardiinae, and intergeneric relationships. Although this is not the first work based on molecular data to test the hypothesis of the monophyly of the Glandulocaudini as currently recognized (see Oliveira et al., 2011 and Thomaz et al., 2015a), the present analysis is the first that focused on the tribe. Furthermore, it includes the most comprehensive taxon-sampling published up to date, including all genera and most species (80\%), with DNA sequences of two species, Glandulocauda caerulea and Mimagoniates sylvicola, analyzed for the first time. The molecular phylogenetic hypotheses presented herein supports Glandulocaudini as a monophyletic group to includes Lophiobrycon, Glandulocauda, and Mimagoniates, as previously proposed by both morphological (e.g., Menezes, Weitzman, 2009; Mirande, 2010) and molecular (e.g., Oliveira et al., 2011; Thomaz et al., 2015a) analyses. Thomaz et al. (2015a: 18) placed Argopleura Eigenmann as 
an incertae sedis genus in Stevardiinae since its relationships with the tribes Glandulocaudini and Stevardiini were not clearly resolved. Likewise, those authors also suggested that Argopleura might be included in Glandulocaudini, but with such hypothesis pending further investigation. In this study, additional sequences of representatives of Glandulocaudini besides $A$. chocoensis were incorporated and the phylogenetic results did not corroborate the hypothesis of placement of Argopleura within this tribe (Fig. 1).

The position of Glandulocaudini within the Stevardiinae is unclear, since BI results indicated a close relationship to the tribe Stevardiini while the ML results suggested Glandulocaudini as sister to the clade ((Creagrutini, Diapomini) Hemibryconini). According to Thomaz et al. (2015a), Glandulocaudini is sister to Stevardiini, however, this clade was not strongly supported ( $\mathrm{ML}=44 \%$, see their fig. 3 ). It indicates that the position of the tribe is controversial in the subfamily. The assessment of the relationships between Glandulocaudini and other tribes of Stevardiinae was not a primary objective of the present paper, thus this issue will not discuss in depth. However, all available information suggests a putative relationship between Glandulocaudini and Stevardiini; despite the reduced taxon sampling, previous phylogenetic studies based on both morphology (e.g., Mirande, 2010) and DNA sequences (e.g., Calcagnotto et al., 2005; Javonillo et al., 2010; Oliveira et al., 2011) also proposed a close relationship between Glandulocaudini and Stevardiini sensu Thomaz et al. (2015a).

A major source of incongruence between previous morphological and molecular phylogenetic hypotheses lay in the intergeneric relationships within the Glandulocaudini. According to morphological studies (e.g., Castro et al., 2003; Menezes, Weitzman, 2009), Glandulocauda is closely related to Mimagoniates and the clade consisting of those taxa is sister to Lophiobrycon. However, in both previous hypotheses based on DNA sequences (i.e., Oliveira et al., 2011; Thomaz et al., 2015a), Glandulocauda appears as sister to Lophiobrycon and this clade related to Mimagoniates. In the present hypothesis, one species of Glandulocauda, $G$. melanopleura, is recovered as sister to Lophiobrycon while the other, G. caerulea, is closely related to the Mimagoniates species. The non-monophyletic status of this genus will be discussed below, but considering that G. melanopleura is its type species, the present hypothesis is in agreement with previous molecular studies. According to Menezes, Weitzman (2009: 301), the clade Glandulocauda plus Mimagoniates is supported by the presence of branching of the anterior pelvic-fin ray (character 8, state 1) (although the character 7 has also been indicated in the topology; see their fig. 2). However, the variation of this feature pointed by these authors ( $c f$. Menezes, Weitzman, 2009: 312, 313, 326, and fig. 17), also observed in additional material analyzed herein (e.g., G. melanopleura: MZUSP 108577, MZUSP 111017; M. inequalis: UFRGS 18074; M. microlepis: MZUSP 112396, 112651,), indicates that this apomorphic condition is polymorphic and should be reevaluated.
The hypothesis of non-monophyly of the genus Glandulocauda. According to the present phylogenetic hypothesis, the genus Glandulocauda as currently composed is not supported as monophyletic, since G. caerulea and $G$. melanopleura are not closely related to each other. This study is the first test of the monophyly of Glandulocauda based on molecular data since DNA sequences of $G$. caerulea have never been analyzed before. The phylogenetic hypotheses based on each dataset separately (16S, $537 \mathrm{bp}$; COI, $522 \mathrm{bp}$; and RAG2, $770 \mathrm{bp}$ ) also did not recover the genus as monophyletic (results not shown). The monophyly of Glandulocauda was not questioned in the morphological hypothesis of Menezes, Weitzman (2009). Although the graphical representation of their topology is somewhat confused (see their fig. 2), the analysis of the text, matrix (see their tab. 1), and the synapomorphies indicated at the nodes leave no doubt that G. caerulea and G. melanopleura were recovered as closely related. According to those authors, this clade is supported by two synapomorphies found in mature males of both species: principal caudal-fin rays 11 and 12 slightly decurved ventrally but not involved in the formation of a pump (character 7 , state 1) plus the presence of glandular tissue widespread along principal caudal-fin rays 10-15 (character 12, state 2). A large number of specimens of both species (see Material examined) was analyzed, including topotypes used herein in the molecular analyses and, besides these synapomorphies, all other diagnostic characters presented by Eigenmann (1911) and Menezes, Weitzman (2009) to characterize the genus were observed. Furthermore, no morphological feature that justify the transfer of G. caerulea to Mimagoniates or the proposition of a new genus to allocate this species was found. Considering this and prioritizing the taxonomic stability, taxonomic changes within the genus are not proposed at this moment.

\section{The genus Mimagoniates and phylogenetic relationships} among its species. In despite of this study represents the most comprehensive taxon sampling analysis based on molecular data for Mimagoniates, the monophyly of this genus could not be properly tested due to absence of tissue samples of its type species, M. barberi. For the same reason, the position of $M$. pulcher within the genus is unknown. While this species has been recently described (see Menezes, Weitzman, 2009), its description was based on specimens collected in 1934 in an uncertain locality in the Mato Grosso State and, until the moment, only the type material is known (holotype, MNRJ 17814 and 28 paratypes, MNRJ 4233), despite of several unsuccessful attempts to recollect this species. In despite of that, a well-supported clade contained five of the seven valid species of Mimagoniates was recovered. Similar results were obtained by previous molecular hypotheses (e.g., Javonillo et al., 2010; Thomaz et al., 2015a). Therefore, apparently there is no doubt about the monophyletic status of this genus. Although the monophyly of Mimagoniates is well supported in the most current morphological hypothesis (i.e., Menezes, Weitzman, 2009), 
its internal relationships are poorly resolved. According to those authors, there are two subclades within Mimagoniates: a trichotomy composed of M. barberi, M. pulcher, and $M$. inequalis and a polytomy containing the remaining species, M. lateralis, M. microlepis, $M$. rheocharis, and M. sylvicola. In the present hypothesis, there were no polytomies and the relationships among Mimagoniates species were fully resolved and received strong statistical support. Among the previous molecular hypotheses, only those of Javonillo et al. (2010) and Thomaz et al. (2015a) included more than one species of Mimagoniates and, in both, M. inequalis and $M$. rheocharis also appeared as closely related to each other, as found herein. According to Thomaz et al. (2015a), this clade is sister to M. microlepis, but sequences of M. lateralis and M. sylvicola were not analyzed. The phylogenetic relationships proposed by Javonillo et al. (2010: fig. 6) were ((M. inequalis, M. rheocharis) (M. lateralis (M. microlepis, Mimagoniates sp.))).

The voucher' specimen of Mimagoniates sp. used by those authors was verified (former UFRGS 10001, currently UFRGS 12442) and, in fact, this is another individual of $M$. microlepis. Therefore, the current hypothesis disagrees on the placement of $M$. lateralis, proposed herein as related to (M. inequalis, $M$. rheocharis), but to M. microlepis by Javonillo et al. (2010), who did not include sequences of $M$. sylvicola in their analysis.

As emphasized by Menezes, Weitzman (2009), their phylogenetic hypothesis was mainly based on the analyses of primary and secondary sexual characters of fully sexually active mature males. In total, Menezes, Weitzman (2009) proposed 14 characters, but these were not sufficiently enlightening with respect to Mimagoniates species, due to the polytomies observed. Thus, for a better understanding of the internal relations in this genus, it is suggested to perform a comprehensive total evidence analysis, which includes, in addition to the present molecular data, morphological characters additional to those already used by those authors. In addition, this analysis will allow the inclusion of $M$. barberi and M. pulcher in the matrix, even if tissue samples are not available for the molecular subdataset.

\section{Biogeographic history of Glandulocaudini: distributional pattern and estimates of divergence times. According to} Menezes et al. (2008) and Menezes, Weitzman (2009), the northernmost limit of distribution of Glandulocaudini is around the city of Prado, in the southern part of the Bahia State, at the type locality of M. sylvicola. However, this species also occurs in some small coastal drainages of the Recôncavo Sul basin (Burger et al., 2011) in addition to the Pardo, Paraguaçu, and Real river basins (Camelier, Zanata, 2014; present study, MZUSP 112657, 112679, 115092, UFBA 7004), located in the Bahia State, but to the north of the Prado region. The rio Real basin is the boundary between Bahia and Sergipe States and it becomes the northernmost limit of the distribution of both M. sylvicola and the tribe Glandulocaudini (Fig. 3). These new data indicate that $M$. sylvicola is more widespread than historically thought (see Menezes et al, 2008: fig. 3) and that it occurs not only in blackwater (e.g., Menezes, Weitzman, 1990; Menezes et al., 2007), but also in "whitewater" streams (e.g., rio Real basin). The relatively disjunct distribution of this species associated to environmental degradation processes that occurred throughout the coastal plain of Brazil (Menezes et al., 2007) suggest that M. sylvicola probably had a more contiguous distribution in the past along coastal streams of Bahia. Extirpation, however, may have been responsible for its current allopatric distributional pattern. According to Menezes, Weitzman (2009), all species of Glandulocaudini are subject to local extirpation because of its environmental requirements (e.g., cool flowing waters, forested areas), which are becoming increasingly rare.

As aforementioned, species of Glandulocauda and Lophiobrycon have a distribution apparently restricted to streams draining upland areas of the Brazilian crystalline shield, whereas the species of Mimagoniates occur mainly in the lowland streams along the eastern and southeastern areas of Brazil (Menezes et al., 2008; Menezes, Weitzman, 2009). The single valid species of Lophiobrycon, L. weitzmani, is considered endemic to headwater streams in the middle rio Grande basin, a tributary to the upper rio Paraná ( $c f$. Castro et al., 2003, Menezes et al., 2008, Menezes, Weitzman, 2009; Eschmeyer et al., 2017). However, specimens belonging to L. weitzmani (LBP 11820) were recently (2011) collected in a small tributary of the upper course of the rio São Francisco basin, in São Roque de Minas, Minas Gerais State. Part of this material was analyzed in this study and the identification of the species was confirmed, representing the first record of L. weitzmani outside the upper Paraná basin and also the first record of a species of the tribe Glandulocaudini in the rio São Francisco basin. In spite of this new record, Lophiobrycon still has a restricted distribution in headwater streams draining the southeastern portion of the Brazilian crystalline shield (Fig. 3). The sharing of fish species that have a relatively restricted distribution, such as $L$. weitzmani, between the uppermost tributaries of the São Francisco and Paraná rivers may be an evidence of historical relationships between these basins already proposed in previous studies (e.g., Ribeiro, 2006; Buckup, 2011; Camelier, Zanata, 2014). Unfortunately, tissue samples of the specimens from the rio São Francisco basin were not available for molecular analyses, thus the age of the split between these populations of $L$. weitzmani could not be estimated.

The molecular clock results indicated the origin of the Glandulocaudini during the late Miocene (14.1 Mya) and the estimated diversification dates in the group were within the Neogene (Miocene and Pliocene) to Pleistocene (10.81.4 Mya) (Fig. 2). Several authors have already discussed the biogeography of the Glandulocaudini species (e.g., Weitzman et al., 1988; Menezes, Weitzman, 1990; Ribeiro, 2006; Ribeiro et al., 2006; Menezes et al., 2008) and most of the them suggested that the initial diversification of the group took place in upland areas of the ancient Brazilian 
crystalline shield, at some paleodrainage of the upper rio Paraná basin. The molecular clock results corroborate this hypothesis since the oldest split occurred among lineages of Glandulocaudini that were restricted to the Brazilian crystalline shield, in the upper rio Paraná basin. According to some authors (e.g., Ribeiro et al., 2006, 2016; Menezes et al., 2008), the occupation of the Atlantic coastal drainages was posterior and probably due to several river capture events associated with strong tectonic activity that affected a large area in eastern and southeastern Brazil during the Paleogene and Neogene. The results also corroborate this hypothesis, since the oldest cladogenetic events within Mimagoniates, a genus typical of lowland coastal, were estimated to have occurred near the end of Miocene (Neogene) about 6.8 Mya. Also, these results indicate that the minimum age of 2.5 My for Mimagoniates speculated by Menezes et al. (2008) based on phylogenetic and geomorphological data was underestimated. According to Thomaz et al. (2015b, 2017), paleoconnections due to sea level retreat played a significant role in the diversification and distributional pattern of the ichthyofauna in lowland along the Brazilian coastal drainages. Although Ribeiro (2006) and Menezes et al. (2008) have questioned these events as being the main causal mechanism promoting cladogenesis and speciation within Glandulocaudini, as previously proposed by Weitzman et al. (1988), present divergence time results corroborate this hypothesis. Thus, apparently, Pleistocene sea-level fluctuations also influenced the current distribution pattern of Mimagoniates, especially at the population level. According to Ribeiro (2006), there are strong evidences that the upper rio Tietê basin suffered a posterior input of an ichthyofauna once found only in coastal rivers where it was endemic. Estimates of divergence times among allopatric populations of $M$. microlepis proposed herein provide an additional evidence to this hypothesis, since the split between populations from some coastal basins are oldest than those involving population from upper rio Tietê. The phylogenetic hypotheses and estimated dates of splits within Glandulocaudini also corroborate the hypothesis of Ribeiro (2006) that this tribe represents an example of the his "biogeographic B pattern". This pattern includes taxa with intermediate biogeographic histories resulting from continued faunal interchanges between the upland Brazilian crystalline shield and coastal rivers throughout the Tertiary (Paleogene and Neogene) (Ribeiro, 2006). According to the present results, the biogeographic history of the Glandulocaudini was shaped mainly by events that occurred during the Neogene (Miocene and Pliocene).

Material examined. All from Brazil. Glandulocauda caerulea: rio Iguaçu basin: MNRJ 19537, 5, 34.4-40.8 mm SL. MZUSP 97663, 5, 21.9-40.8 mm SL. MZUSP 97664, 5, 26.6-41.8 mm SL. MZUSP 97665, 2, 30.1-46.5 SL. MZUSP 97666, 3 + 1 c\&s, 34.3-38.7 mm SL. MZUSP 117479, 4, 28.9-34.1 mm SL. Glandulocauda melanopleura: rio Guaratuba basin: MZUSP 84412, 10, 19.237.2 mm SL. MZUSP 87567, 23, 18.2-36.1 mm SL. MZUSP
87571, $43+1$ c\&s, 29.5-44.0 mm SL. MZUSP 115244, $20+12$ mol, 33.0-39.4 mm SL. rio Itanhaém basin: MZUSP 108577, 2, 29.7-36.2 mm SL. MZUSP 108621, 8, 24.3-31.9 mm SL. MZUSP 108724, 1, $54.0 \mathrm{~mm}$ SL. MZUSP 111017, $22+2 \mathrm{c} \& \mathrm{~s}+10 \mathrm{~mol}$, 14.5-57.4 mm SL. rio Itatinga basin: DZSJRP 6613, 2, 26.2-26.6 mm SL. rio Ribeira de Iguape basin: MZUSP 79429, 3, 37.5-48.9 $\mathrm{mm}$ SL. rio Tietê basin: LBP 4507, $10+7 \mathrm{~mol}$, 40.5-45.0 mm SL. MZUSP 26891, 3, 43.4-52.3 mm SL. MZUSP 28849, 10, 26.9 $32.7 \mathrm{~mm}$ SL. MZUSP 35242, 8, $1 \mathrm{c} \& \mathrm{~s}, 33.8-39.1 \mathrm{~mm}$ SL. MZUSP 74333, $10+1$ c\&s, 25.2-30.2 mm SL. MZUSP 86967, 3, 43.6-57.5 mm SL. MZUSP 86984, 2, 24.9-44.0 mm SL.

\section{Acknowledgments}

We are grateful to Cristina Y. Miyaki (USP), Carlos David de Santana (NMNH), Fernando Carvalho (UFMS), Luiz R. Malabarba (UFRGS), Mário de Pinna, Osvaldo T. Oyakawa (MZUSP), and Roberto Reis (PUCRS) for valuable suggestions on the manuscript. For the loan of comparative material and/or donation of tissue samples, we are grateful to Angela M. Zanata (UFBA), Carlos Lucena (MCP), Francisco Langeani (DZSJRP), Luiz R. Malabarba (UFRGS), Marcelo Britto and Cristiano Moreira (MNRJ). We thank Angela M. Zanata (UFBA), Camila Souza (UNESP), José C. Nolasco, Marcelo R. S. Melo (IO-USP), Osvaldo T. Oyakawa (MZUSP), Renato Devidé (UNESP), and Túlio Teixeira for help in the field. Luz E. Ochoa (UNESP) helped with the amplifications of the gene RAG2. Authors were funded by FAPESP (PC: grant \# 2012/008406 and 2016/03966-1; CO: grant \# 2014/26508-3) and CNPq (CO: grant \# 306054/2006-0). This study also received support from the South American Characiformes Inventory Project (FAPESP 2011/50282-7).

\section{References}

Buckup PA. The Eastern Brazilian Shield. In: Albert JS, Reis RE, editors, Historical Biogeography of Neotropical Freshwater Fishes. California: University of California Press; 2011. p.203210.

Bührnheim CM, Carvalho TP, Malabarba LR, Weitzman SW. A new genus and species of characid fish from the Amazon basin - the recognition of a relictual lineage of characid fishes (Ostariophysi: Cheirodontinae: Cheirodontini). Neotrop Ichthyol [serial on the internet]. 2008; 6(4):663-78. Available from: http://dx.doi.org/10.1590/S1679-62252008000400016

Burger R, Zanata AM, Camelier P. Estudo taxonômico da ictiofauna de água doce da bacia do Recôncavo Sul, Bahia, Brasil. Biota Neotropica [serial on the internet]. 2011; 11(4):273-90. Available from: http://dx.doi.org/10.1590/ S1676-06032011000400024

Calcagnotto D, Schaefer SA, DeSalle R. Relationships among characiform fishes inferred from analysis of nuclear and mitochondrial gene sequences. Mol Phylogenet Evol [serial on the internet]. 2005; 36(1):135-53. Available from: https:/doi. org/10.1016/j.ympev.2005.01.004 
Camelier P. Especiação e biogeografia nos gêneros Glandulocauda Eigenmann e Mimagoniates Regan (Characidae: Stevardiinae: Glandulocaudini). [PhD Thesis]. São Paulo, SP: Universidade de São Paulo; 2016 [cited 2017 Dec 9]. Available from: Biblioteca digital Universidade de São Paulo. http://www.teses. usp.br/teses/disponiveis/38/38131/tde-01072016-172006/ptbr.php

Camelier P, Zanata AM. Biogeography of freshwater fishes from the Northeastern Mata Atlântica freshwater ecoregion: distribution, endemism, and area relationships. Neotrop Ichthyol [serial on the internet]. 2014; 12(4):683-98. Available from: http://dx.doi. org/10.1590/1982-0224-20130228

Castro RMC, Ribeiro AC, Benine RC, Melo ALA. Lophiobrycon weitzmani, a new genus and species of glandulocaudine fish (Characiformes: Characidae) from the rio Grande drainage, upper rio Paraná system, southeastern Brazil. Neotrop Ichthyol [serial on the internet]. 2003; 1(1):11-9. Available from: http:// dx.doi.org/10.1590/S1679-62252003000100002

Cohen KM, Finney SC, Gibbard PL, Fan JX. The ICS International Chronostratigraphic Chart. Episodes. 2013; 36(3):199-204. Available from: www.stratigraphy.org/ICSchart/Cohen2013_ Episodes.pdf

Drummond AJ, Ho SYW, Phillips MJ, Rambaut A. Relaxed phylogenetics and dating with confidence. PLoS Biol [serial on the internet]. 2006; 4(5):699-710. Available from: https://doi. org/10.1371/journal.pbio.0040088

Drummond AJ, Suchard MA, Xie D, Rambaut A. Bayesian phylogenetics with BEAUti and the BEAST 1.7. Mol Biol Evol [serial on the internet]. 2012; 29(8):1969-73. Available from: https://doi.org/10.1093/molbev/mss075

Edgar R. Muscle: a multiple sequence alignment method with reduced time and space complexity. BMC Bioinformatics [serial on the internet]. 2004; 5(113):1-19. Available from: https://doi.org/10.1186/1471-2105-5-113

Eigenmann $\mathrm{CH}$. New characins in the collections of the Carnegie Museum. Ann Carnegie Mus. 1911; 8:164-81.

Eigenmann $\mathrm{CH}$. Some results from studies of South American fishes. II. The Glandulocaudinae (a new subfamily of characid fishes with innate potentialities for sexual dimorphism). Indiana University Studies. 1914; 20:32-35.

Eschmeyer WN, Fricke R, van der Laan R, editors. Catalog of fishes: genera, species, references [Internet]. San Francisco: California Academy of Science; 2017 [cited 2017 Dec 9]. Available from: http://researcharchive.calacademy.org/ research/ichthyology/catalog/fishcatmain.asp)

Fernández-Yépez A, Antón JR. Estudio (analisis) ictiologico "Las Majaguas". Republica de Venezuela: Direccion de Obras Hidraulicas, Ministerio de Obras Publicas; 1966.

Forest F. Calibrating the Tree of Life: fossils, molecules and evolutionary timescales. Ann Bot [serial on the internet]. 2009; 104(5):789-94. Available from: https://doi.org/10.1093/aob/ mcp 192

Fricke R, Eschmeyer WN. Guide to fish collections [Internet]. San Francisco: California Academy of Science; 2017 [cited 2017 Dec 9]. Available from: http://researcharchive.calacademy.org/ research/ichthyology/catalog/collections.asp

Gelman A, Donal BR. Inference from iterative simulation using multiple sequences. Stat Sci. 1992; 457-72.

Hall TA. BioEdit: a user-friendly biological sequence alignment editor and analysis program for Windows 95/98/NT. Nucleic Acids Symp Ser (Oxf). 1999; 41:95-98.
Javonillo R, Malabarba LR, Weitzman SH, Burns JR. Relationships among major lineages of characid fishes (Teleostei: Ostariophysi: Characiformes), based on molecular sequence data. Mol Phylogenet Evol [serial on the internet]. 2010; 54(2):498-511. Available from: https://doi. org/10.1016/j.ympev.2009.08.026

Kearse M, Moir R, Wilson A, Stones-Havas S, Cheung M, Sturrock S, et al. Geneious Basic: an integrated and extendable desktop software platform for the organization and analysis of sequence data. Bioinformatics [serial on the internet]. 2012; 28(12):1647-9. Avaiable from: https://doi. org/10.1093/bioinformatics/bts 199

Lima FCT, Ribeiro AC. Continental-Scale Tectonic Controls of Biogeography and Ecology. In: Albert JS, Reis RE, editors, Historical Biogeography of Neotropical Freshwater Fishes. California: University of California Press; 2011. p.145-184.

Malabarba MC. Phylogeny of fossil Characiformes and paleobiogeography of the Tremembé Formation, São Paulo, Brazil. In: Malabarba LR, Reis RE, Vari RP, Lucena ZS, Lucena CS, editors. Phylogeny and Classification of Neotropical Fishes. Porto Alegre: Edipucrs; 1998. p.69-84.

Menezes NA, Weitzman SH. Two new species of Mimagoniates (Teleostei: Characidae: Glandulocaudinae), their phylogeny and biogeography and a key to the glandulocaudin fishes of Brazil and Paraguay. Proc Biol Soc Wash. 1990; 103:380-426.

Menezes NA, Weitzman SH. Systematics of the Neotropical fish subfamily Glandulocaudinae (Teleostei: Characiformes: Characidae). Neotrop Ichthyol [serial on the internet]. 2009; 7(3):295-370. Available from: http://dx.doi.org/10.1590/ S1679-62252009000300002

Menezes NA, Ribeiro AC, Weitzman SH, Torres RA. Biogeography of the Glandulocaudinae (Teleostei: Characiformes: Characidae) revisited: phylogenetic patterns, historical geology and genetic connectivity. Zootaxa. 2008; 1726:33-48.

Menezes NA, Weitzman SH, Oyakawa OT, Lima FCT, Castro RMC, Weitzman MJ. Peixes de água doce da Mata Atlântica: lista preliminar de espécies e comentários sobre conservação de peixes de água doce neotropicais. São Paulo: Museu de Zoologia da Universidade de São Paulo; 2007.

Miller M, Pfeiffer W, Schwartz T. Creating the CIPRES science gateway for inference of large phylogenetic trees. Gateway Computing Environments Workshop (GCE). 2010; 1-8. Available from: https://doi.org/10.1109/GCE.2010.5676129

Mirande JM. Phylogeny of the family Characidae (Teleostei: Characiformes) from characters to taxonomy. Neotrop Ichthyol [serial on the internet]. 2010; 8(3):385-568. Available from: http://dx.doi.org/10.1590/S1679-62252010000300001

Mirande JM, Jerep FC, Vanegas-Ríos JA. Phylogenetic relationships of the enigmatic Carlastyanax aurocaudatus (Eigenmann) with remarks on the phylogeny of the Stevardiinae (Teleostei: Characidae). Neotrop Ichthyol [serial on the internet]. 2013; 11(4):747-66. Available from: http://dx.doi.org/10.1590/S1679-62252013000400003

Myers GS, Böhlke JE. The Xenurobryconini, a group of minute South American characid fishes with teeth outside the mouth. Stanf Ichthyol Bull. 1956; 7(2):6-12.

Nylander JAA. MrModeltest v2. Program distributed by the author. Evolutionary Biology Centre, Uppsala University. 2004. 
Oliveira C, Avelino GS, Abe KT, Mariguela TC, Benine RC, Ortí $\mathrm{G}$, et al. Phylogenetic relationships within the speciose family Characidae (Teleostei: Ostariophysi: Characiformes) based on multilocus analysis and extensive ingroup sampling. BMC Evol Biol [serial on the internet]. 2011; 11(275):1-25. Available from: https://doi.org/10.1186/1471-2148-11-275

Palumbi SR. Nucleic acids II: the polymerase chain reaction. In: Hillis D, Moritz C, Mable B, editors. Molecular Systematics. Sunderland: Sinauer Associates Inc; 1996. p.205-247.

Rambaut A. FigTree [computer program], version 1.3.1. 2009. Available from http:// tree.bio.ed.ac.uk/software/figtree/

Rambaut A, Drummond AJ. Tracer [computer program], version 1.5. 2009. Available from: http://tree.bio.ed.ac.uk/ software/tracer

Ribeiro AC. Tectonic history and the biogeography of the freshwater fishes from the coastal drainages of eastern Brazil: an example of faunal evolution associated with a divergent continental margin. Neotrop Ichthyol [serial on the internet]. 2006; 4(2):225-46. Available from: http://dx.doi.org/10.1590/S167962252006000200009

Ribeiro AC, Lima FCT, Menezes NA. Biogeografia dos Peixes de Água Doce da América do Sul. In: Carvalho CJB, Almeida EAB, editors. Biogeografia da América do Sul: análise de tempo, espaço e forma. Rio de Janeiro: Roca; 2016. p.245-258.

Ribeiro AC, Lima FCT, Ricomini C, Menezes NA. Fishes of the Atlantic Rainforest of Boracéia: testimonies of the Quaternary fault reactivation within a Neoproterozoic tectonic province in Southeastern Brazil. Ichthyol Explor Freshw. 2006; 17(2):157-64.

Ronquist F, Teslenko M, van der Mark P, Ayres DL, Darling A, Höhna S, et al. MrBayes 3.2: Efficient Bayesian Phylogenetic Inference and Model Choice Across a Large Model Space. Syst Biol [serial on the internet]. 2012; 61(3):539-42. Available from: https://doi.org/10.1093/sysbio/sys029

Serra JP, Carvalho FR, Langeani F. Ichthyofauna of the rio Itatinga in the Parque das Neblinas, Bertioga, São Paulo State: composition and biogeography. Biota Neotropica [serial on the internet]. 2007; 7:81-86. Available from: https://dx.doi.org/10.1590/ S1676-06032007000100011

Stamatakis A. RAxML Version 8: A tool for Phylogenetic analysis and post-analysis of large phylogenies. Bioinformatics [serial on the internet]. 2014; 30(9):1312-3. Available from: https://doi. org/10.1093/bioinformatics/btu033

Swofford DL. PAUP*. Phylogenetic Analysis Using Parsimony (*and Other Methods). Version 4.0. Sinauer Associates, Sunderland, Massachusetts. 1998.

Tamura K, Peterson D, Peterson N, Stecher G, Nei M, Kumar S. MEGA5: Molecular Evolutionary Genetics Analysis Using Maximum Likelihood, Evolutionary Distance, and Maximum Parsimony Methods. Mol Biol Evol [serial on the internet]. 2011; 28(10):2731-9. Available from: https://doi.org/10.1093/ molbev/msr121

Thomaz AT, Arcila D, Ortí G, Malabarba LR. Molecular phylogeny of the subfamily Stevardiinae Gill, 1858 (Characiformes: Characidae): classification and the evolution of reproductive traits. BMC Evol Biol [serial on the internet]. 2015a; 15(146):125. Available from: https://doi.org/10.1186/s12862-015-0403-4
Thomaz AT, Malabarba LR, Bonatto SL, Knowles LL. Testing the effect of palaeodrainages versus habitat stability on genetic divergence in riverine systems: study of a Neotropical fish of the Brazilian coastal Atlantic Forest. J Biogeogr [serial on the internet]. 2015b; 1-13. Available from: https://doi.org/10.1111/ jbi.12597

Thomaz AT, Malabarba LR, Knowles LL. Genomic signatures of paleodrainages in a freshwater fish along the southeastern coast of Brazil: genetic structure reflects past riverine properties. Heredity [serial on the internet]. 2017; 119:287-94. Available from: https://doi.org/10.1038/hdy.2017.46

Xia X. DAMBE5: A comprehensive software package for data analysis in molecular biology and evolution. Mol Biol Evol [serial on the internet]. 2013; 30(7):1720-8. Available from: https://doi.org/10.1093/molbev/mst064

Xia X, Lemey P. Assessing substitution saturation with DAMBE. In: Lemey P, Salemi M, Vandamme AM, editors. The Phylogenetic Handbook: A Practical Approach to DNA and Protein Phylogeny. Cambridge: University Press; 2009. p.615-630.

Xia X, Xie Z, Salemi M, Chen L, Wang Y. An index of substitution saturation and its application. Mol Phylogenet Evol [serial on the internet]. 2003; 26(1):1-7. Available from: https://doi. org/10.1016/S1055-7903(02)00326-3

Ward RD, Zemlak TS, Innes BH, Last PR, Hebert PND. DNA barcoding Australia's fish species. Philos Trans R Soc Lond B Biol Sci [serial on the internet]. 2005; 360:1847-57. Available from: https://doi.org/10.1098/rstb.2005.1716

Weiss FE, Malabarba LR, Malabarba MC. Phylogenetic relationships of Paleotetra, a new characiform fish (Ostariophysi) with two new species from the EoceneOligocene of south-eastern Brazil. J Syst Palaeontol [serial on the internet]. 2012; 10:73-86. Available from: https://doi.org/1 $0.1080 / 14772019.2011 .565082$

Weitzman SH, Fink SV. Xenurobryconin phylogeny and putative pheromone pumps in glandulocaudine fishes (Teleostei: Characidae). Smithson Contrib Zool. 1985; 421:1-121.

Weitzman SH, Menezes NA, Weitzman MJ. Phylogenetic biogeography of the Glandulocaudini (Teleostei: Characiformes, Characidae) with comments on the distributions of other freshwater fishes in eastern and southeastern Brazil. In: Vanzolini PE, Heyer WR, editors. Proceedings of a workshop on Neotropical distribution patterns. Rio de Janeiro: Academia Brasileira de Ciências; 1988. p.379-427.

Weitzman SH, Menezes NA, Burns JR, Evers HG. Putative relationships among inseminating and externally fertilizing characids, with a description of a new genus and species of Brazilian inseminating fish bearing an anal-fin gland in males (Characiformes: Characidae). Neotrop Ichthyol [serial on the internet]. 2005; 3(3):329-60. Available from: http://dx.doi. org/10.1590/S1679-62252005000300002

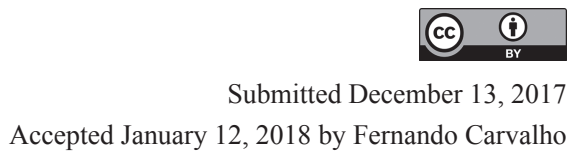

